\title{
Species Diversity and Population Dynamics of Fruit Flies in Guava Ecosystem
}

\author{
Mahesh Math*, Y.K. Kotikal and V.M. Ganiger \\ Department of Entomology, COH, UHS, Bagalkot-587 104, India \\ *Corresponding author
}

\begin{tabular}{|l|}
\hline Ke y w o r d s \\
Guava, Species \\
diversity, Population \\
dynamics, Fruit flies, \\
Northern dry zone
\end{tabular}

\section{A B S T R A C T}

Studies related to species diversity and seasonal incidence of fruit flies in guava ecosystem was conducted at University of Horticultural Sciences (UHS), Udyanagiri, Bagalkot, India during 2015-16 and 2016-17. The species diversity indices of fruit flies during 2015-16 showed that Shannon index of diversity of the fruit fly population was maximum during $48^{\text {th }}$ standard matereological week (SMW) of (November) $2015\left(\mathrm{H}^{\prime}=1.06\right)$, followed by $27^{\text {th }}$ SMW of (July) $2015\left(\mathrm{H}==^{\prime} 0.83\right)$. Maximum $\mathrm{J}^{\prime}$ value was recorded $\left(\mathrm{J}^{\prime}=0.98\right.$ and 0.96 , respectively) during $40^{\text {th }}$ and $51^{\text {st }}$ SMW of 2015 and $1^{\text {st }}, 3^{\text {rd }}$ and $48^{\text {th }}$ SMW 2016. The maximum Simpson diversity index value was recorded (0.84) during $1^{\text {st }}$ SMW of (January) 2016. During 2016-17, Shannon index of diversity of the fruit fly population was maximum during $25^{\text {th }}$ SMW of (June) $2017\left(\mathrm{H}^{\prime}=1.08\right)$. Maximum $\mathrm{J}^{\prime}$ value was recorded (0.98) during $25^{\text {th }}$ SMW followed by $23^{\text {rd }}$ SMW of (June) 2017 (0.95). The maximum Simpson diversity index value (0.84) was recorded during 23rd SMW of (June) 2017. When the total fruit flies were considered irrespective of the species, the first major peak population (80.25 flies per trap/week) was observed during $27^{\text {th }}$ SMW of 2015 and during $29^{\text {th }}$ SMW of (July) 2017 (71.50 fruit flies/trap/week).

\section{Introduction}

The fruit flies, pests of quarantine importance and difficult to control have great impact on Agri or Horti ecosystem causing enormous damage to fruits posing serious threat in guava particularly in northern dry zone of Karnataka, India. In India, the total area under guava cultivation is 2.60 lakh hectares with an annual production of 38.26 lakh metric tonnes (Anonymous, 2017). About 80 species of insects have been recorded on guava (Butani, 1979; Singh et al., 2003) affecting yield and quality of fruits. Spiraling whitefly, guava kajji bug and fruit fly are the major constraints. The Oriental fruit fly, Bactrocera dorsalis Hendel is the most important and destructive pest associated with guava (Verghese and Sudhadevi, 1998 and Rajitha and Viraktamath, 2005). There are very few studies regarding diversity of fruit flies in guava ecosystem particularly in Northern dry zone of Karnataka. Hence the research work was undertaken to record the species diversity and population dynamics of fruit flies in guava ecosystem. 


\section{Materials and Methods}

Studies related to species diversity and seasonal incidence of fruit flies in guava ecosystem was conducted at University of Horticultural Sciences (UHS), Udyanagiri, Bagalkot, India during 2015-16 and 2016-17. The data on seasonal incidence of fruit flies were collected by installing water bottle trap for the period of two years during 2015-16 and 2016-17. A total of four bottle traps were set up at 30 feet apart from each other to avoid the interference of the traps. A bottle trap was prepared using one litre capacity mineral water bottle and made with four holes of 20 $\mathrm{mm}$ diameter on four sides $8 \mathrm{~cm}$ above the bottom. A card board piece of $6 \times 1.5 \times 1.5 \mathrm{~cm}$ was charged with 2 per cent methyl eugenol along with $1 \mathrm{ml}$ malathion in $100 \mathrm{ml}$ of water. Total Number and species of fruit flies trapped in each trap were counted at weekly interval. After each observation traps were emptied. Observations were recorded throughout the year. Methyl eugenol traps were charged at weekly interval. Number of fruit flies trapped per trap per week for each species was averaged and correlated with weather parameters viz., minimum and maximum temperature, minimum and maximum relative humidity, rainfall and wind speed.

\section{Diversity index}

The species diversity was worked out by using the following Simpson's index $(\lambda)$ (Simpson, 1949) and Shannon's Weiner index $\left(\mathrm{H}^{\prime}\right)$ (Shannon and Wiener, 1949) formulae to know the species richness in different ecosystems and within the cropping season at different stages.

Simpson index $=\sum{ }^{\mathrm{S}} \mathrm{Pi}^{2}$

$\mathrm{i}=1$

Where, $\mathrm{Pi}$ is the proportional abundance of the $\mathrm{i}^{\text {th }}$ species given by

$$
\mathrm{Pi}=\underline{\mathrm{ni}}, \mathrm{i}=1,2,3, \ldots \ldots \ldots . \mathrm{S} .
$$

\section{$\mathrm{N}$}

Where, ni number of individuals of the $\mathrm{i}^{\text {th }}$ species and $\mathrm{N}$ is the total number of individuals for all $\mathrm{S}$ species in the population.

Simpson diversity $=1-\sum \mathrm{pi}^{2}$

Where, ni number of individuals of the $\mathrm{i}^{\text {th }}$ species and $\mathrm{N}$ is the total number of individuals for all $\mathrm{S}$ species in the population.

Simpson diversity $=1-\sum \mathrm{pi}^{2}$

Shannon Index $\left(\mathrm{H}^{1)}=\sum^{\mathrm{S}}[\mathrm{Pi}\right.$ In Pi]

$\mathrm{i}=1$

Where, $\mathrm{H}^{1}$ is the average uncertainty per species in an infinite community made up of $\mathrm{S}$ species with known proportional abundance.

$\mathrm{Pi}=\mathrm{P}_{1}, \mathrm{P}_{2}, \mathrm{P}_{3}, \ldots \ldots \ldots \ldots . . \mathrm{PS}$

Where, $\mathrm{Pi}$ is the proportion of individuals found in $\mathrm{i}^{\text {th }}$ species given by ni/N.

ni and $\mathrm{N}$ are the number of individuals of $\mathrm{i}^{\text {th }}$ species and total number of individuals respectively.

\section{Evenness indices}

Indices of evenness of Pielou's $\left(\mathrm{J}^{\prime}\right)$ (Pielous, 1969) were calculated using the following equations.

\section{Pielou's evenness ( $\left.\mathbf{J}^{\prime}\right)$}

$$
\mathbf{J}^{\prime}=\frac{\mathbf{H}^{\prime}}{\operatorname{In}(\mathbf{S})}=\frac{\mathrm{H}^{\prime}}{\mathrm{H} \max }
$$

$\mathrm{H}$ ' is Shannon's Weiner index 
Hmax is the maximum diversity given by In (S).

Where, $\mathrm{S}$ is the total number of species.

To know the diversity of the fruit flies occurring in the guava ecosystem, the collected specimens were mounted on paper point and were also preserved in 70 per cent alcohol with proper label and were sent for identification to Dr. K.J. David, Scientist (Agril. Entomology), Division of Insect Systematics, ICAR-National Bureau of Agricultural Insect Resources, Bengaluru. Species diversity was documented after getting identity of the fruit fly specimens.

\section{Results and Discussion}

A total of five species of fruit flies were identified from guava ecosystem viz., $B$. dorsalis, B. zonata, B. correcta, B. duplicata Bezzi and B.cucurbitae. The species diversity indices of fruit flies during 2015-16 showed that Shannon index of diversity of the fruit fly population was maximum during $48^{\text {th }}$ standard matereological week (SMW) of (November) $2015\left(H^{\prime}=1.06\right)$, followed by $27^{\text {th }}$ SMW of (July) 2015 ( $\mathrm{H}=$ '0.83). A low $\mathrm{H}$ value indicated during particular SMW indicated the low species diversity. The Pielou's evenness $\left(J^{\prime}\right)$ estimated ranged from 0.00 to 0.98 . Maximum $\mathrm{J}^{\prime}$ value was recorded $\left(\mathrm{J}^{\prime}=0.98\right.$ and 0.96 respectively) during $40^{\text {th }}$ and $51^{\text {st }} \mathrm{SMW}$ of 2015 and $1^{\text {st }}, 3^{\text {rd }}$ and $48^{\text {th }}$ SMW 2016. This indicated that species present in the community have equal number of individuals. The low $\mathrm{J}^{\prime}$ value recorded during $30^{\text {th }}$ and $28^{\text {th }}$ SMW of 2015 (0.39 to 0.49) indicated that the species present in the community have unequal number of individuals during particular week. Simpson diversity index ranged from 0.22 to 0.84 . The maximum Simpson diversity index value was recorded (0.84) during $1^{\text {st }}$ SMW of (January) 2016 followed by $3^{\text {rd }}$ SMW of 2016 and $48^{\text {th }}$ SMW of $2016(0.80)$ which indicated that the diversity of fruit fly species was maximum during $1^{\text {st }}$ SMW compared to the other weeks (Table 1).

The species diversity indices of fruit flies in guava during 2016-17 showed a variation in the species diversity in different SMW. Shannon index of diversity of the fruit fly population was maximum during $25^{\text {th }} \mathrm{SMW}$ of (June) $2017\left(\mathrm{H}^{\prime}=1.08\right)$ followed by $23^{\text {rd }}$ SMW of (June) 2017 and 27 ${ }^{\text {th }}$ SMW of (July) 2017 $(\mathrm{H}=1.08$ and 1.04 , respectively). A low $\mathrm{H}$ value indicated that in particular standard week, species diversity was low. The Pielou's evenness $\left(\mathrm{J}^{\prime}\right)$ ranged from 0.00 to 0.98 . Maximum $\mathrm{J}^{\prime}$ value was recorded (0.98) during $25^{\text {th }}$ SMW followed by $23^{\text {rd }}$ SMW of (June) 2017 (0.95). The low J' value was recorded during other standard weeks of 2016-17 indicated that the species present in the community have unequal members of individuals. Simpson diversity index ranged from 0.00 to 0.84 . The maximum Simpson diversity index value (0.84) was recorded during 23rd SMW of (June) 2017 followed by $25^{\text {th }}$ SMW of (June) 2017 (0.73) which indicates that the diversity of fruit fly species was maximum when compared to the other weeks (Table 2). All the species that were observed during the present study have been previously reported from Karnataka (Drew and Raghu, 2002; David and Ramani, 2011). Similarly these three species of Bactrocera were reported on mango and guava from Dharwad district (Ravikumar, 2006 and Rajitha and Viraktamath, 2006). According to Kadam (2012), among the three species viz., $B$. dorsalis, B. zonata, B. correcta, and B. dorsalis was dominant in Rahuri area in guava orchard. But in the present study, the dominant species in guava was $B$. correcta. This might be due to the different locations, host food availability and stage of fruits. Nagaraj et al., (2014) reported that, B. dorsalis was the dominant species in GKVK campus, 
Bangaluru (49.41\%) followed by B. correcta (34.22) and B. zonata (16.35), where as in Srinivaspur of Kolar district, B. correcta was the dominant species with 67.88 per cent followed by $B$. dorsalis $(24.07 \%)$ and $B$. zonata $(8.04 \%)$, which indicates that in certain localities $B$. correcta became dominant replacing $B$. dorsalis for which the reasons are not known. Trap catches of Bactrocera dorsalis Hendel ranged from 0.00-15.00 flies per trap per week.

The highest numbers of $B$. dorsalis males were trapped during $27^{\text {th }}$ SMW of July 2015 with a trap catches of 15.00 flies per trap per week. The catches declined rapidly reaching zero during $43^{\text {rd }}$ SMW. The fruit flies gradually disappeared from $45^{\text {th }}$ SMW. The highest number of $B$. correcta was trapped during $27^{\text {th }}$ SMW with trap catches of 55.75 fruit flies per trap per week. Again a small peak activity was observed during $42^{\text {nd }}$ SMW (28.75 flies/trap/week). The catches declined reaching the lowest catches of 3.00 fruit flies per trap per week during $39^{\text {th }}$ SMW. The catches declined rapidly after $46^{\text {th }}$ SMW. The population of $B$. zonata was at the lower level throughout the study period. The trap catches varied from 0.00 to 9.50 fruit flies per trap per week during 2015-16. The highest catches were recorded during $27^{\text {th }}$ SMW (9.50 fruit flies/trap/week) and then the population was at lower level and disappeared from $33^{\text {rd }}$ SMW till $3^{\text {rd }}$ SMW with irregular lower appearance (Table 3). When the total fruit flies were considered irrespective of the species, the first major peak population of 80.25 fruit flies per trap per week was observed during $27^{\text {th }}$ SMW. The population declined to 3.00 fruit flies per trap per week during $45^{\text {th }} \mathrm{SMW}$ and remained more or less at the same level from $40^{\text {th }}$ SMW to $3^{\text {rd }}$ SMW (Table 3). Trap catches of $B$. dorsalis ranged from 0.50 to 9.50 flies per trap per week. The highest numbers of $B$. dorsalis males were trapped during $28^{\text {th }} \mathrm{SMW}$ of (July) 2017 (trap catches of 9.50 flies/trap/week).
The fruit fly catches declined rapidly reaching zero during $30^{\text {th }}$ SMW. The catches remained more or less similar after $30^{\text {th }} \mathrm{SMW}$ to $48^{\text {th }}$ SMW during 2016. There was no fruit fly activity observed after $49^{\text {th }}$ SMW of 2016 to $20^{\text {th }}$ SMW of 2017 . The peak activity of $B$. correcta was noticed during $26^{\text {th }}$ SMW to $29^{\text {th }}$ SMW with highest peak during $29^{\text {th }}$ SMW of (July) 2017 (60.50 flies/trap/week). The fruit fly activity declined after $30^{\text {th }}$ SMW reached another small peak during $40^{\text {th }}$ SMW of (October) 2016 (8.50 flies/trap/week). No fruit fly activity was observed from $1^{\text {st }}$ SMW to $18^{\text {th }}$ SMW of 2016. The population of $B$. zonata was at the lower level throughout the study period. The trap catches varied from 0.00 to 4.00 fruit flies per trap per week during 2016-17. The highest catches were recorded during $27^{\text {th }}$ SMW. After $30^{\text {th }}$ SMW fruit fly catches were lowest ranging from 0.00 to 1.50 flies per trap per week and remained constant up to $46^{\text {th }}$ SMW of (November) 2016. No fruit fly activity was observed during $50^{\text {th }}$ SMW of (December) 2016 to $22^{\text {nd }}$ SMW of (May) 2017. Considering the total number of fruit flies irrespective of the species, the first major peak (71.50 fruit flies/trap/week) was observed during $29^{\text {th }}$ SMW of (July) 2017. The next smaller peak activity was observed during $36^{\text {th }}$ SMW of (September) 2016 (11.00). No fruit fly catches (0.00 flies/trap/week) observed during $1^{\text {st }}$ SMW of (January) 2017 to $18^{\text {th }}$ SMW of (May) 2017 (Table 4).

Jalaluddin et al., (2001) reported that population of guava fruit fly, B. correcta, in guava orchards showed a distinct population peak, which coincided with the fruit ripening and was recorded from July to August in both years. Chaudhary and Jamal (2002) observed peak activity of $B$. zonata and $B$. dorsalis from August to October, which coincided with the maturity of guava under various environmental conditions of Rawalpindi, Pakistan. 
Table.1 Species diversity indices for fruit flies in guava during 2015-16

\begin{tabular}{|c|c|c|c|c|}
\hline SMW & $\begin{array}{l}\text { Shannon's } \\
\text { index (H') }\end{array}$ & $\begin{array}{c}\text { Pielou's } \\
\text { evenness }\left(\mathbf{J}^{\prime}\right)\end{array}$ & $\begin{array}{c}\text { Simpson index } \\
\text { (D) }\end{array}$ & $\begin{array}{c}\text { Simpson } \\
\text { diversity index } \\
(1-D) \\
\end{array}$ \\
\hline 27 & 0.83 & 0.76 & 0.52 & 0.48 \\
\hline 28 & 0.54 & 0.49 & 0.70 & 0.30 \\
\hline 29 & 0.72 & 0.66 & 0.58 & 0.42 \\
\hline 30 & 0.43 & 0.39 & 0.78 & 0.22 \\
\hline 31 & 0.74 & 0.67 & 0.57 & 0.43 \\
\hline 32 & 0.78 & 0.71 & 0.55 & 0.45 \\
\hline 33 & - & - & - & - \\
\hline 34 & 0.67 & 0.97 & 0.49 & 0.51 \\
\hline 35 & 0.43 & 0.62 & 0.71 & 0.29 \\
\hline 36 & 0.46 & 0.66 & 0.71 & 0.29 \\
\hline 37 & 0.42 & 0.61 & 0.72 & 0.28 \\
\hline 38 & 0.53 & 0.76 & 0.62 & 0.38 \\
\hline 39 & - & - & - & - \\
\hline 40 & 0.68 & 0.98 & 0.40 & 0.60 \\
\hline 41 & 0.81 & 0.74 & 0.50 & 0.50 \\
\hline 42 & 0.63 & 0.57 & 0.65 & 0.35 \\
\hline 43 & - & - & - & - \\
\hline 44 & 0.55 & 0.79 & 0.60 & 0.40 \\
\hline 45 & - & - & - & - \\
\hline 46 & 0.00 & 0.00 & 0.00 & 0.00 \\
\hline 47 & - & - & - & - \\
\hline 48 & 1.06 & 0.96 & 0.20 & 0.80 \\
\hline 49 & - & - & - & - \\
\hline 50 & - & - & - & - \\
\hline 51 & 0.68 & 0.98 & 0.31 & 0.69 \\
\hline 52 & - & - & - & - \\
\hline 1 & 0.68 & 0.98 & 0.16 & 0.84 \\
\hline 2 & 0.00 & 0.00 & 0.00 & 0.00 \\
\hline 3 & 0.68 & 0.98 & 0.20 & 0.80 \\
\hline
\end{tabular}

SMW- Standard Meteorological Weeks

(*There was no incidence of fruit flies in guava from $4{ }^{\text {th }}$ to $26^{\text {th }}$ SMW during 2016)

(- Species diversity was not noticed) 
Table.2 Species diversity indices for fruit flies in guava during 2016-17

\begin{tabular}{|c|c|c|c|c|}
\hline SMW & $\begin{array}{l}\text { Shannon's } \\
\text { index }\left(H^{\prime}\right)\end{array}$ & $\begin{array}{c}\text { Pielou's } \\
\left.\text { evenness ( } \mathbf{J}^{\prime}\right)\end{array}$ & $\begin{array}{l}\text { Simpson index } \\
\text { (D) }\end{array}$ & $\begin{array}{c}\text { Simpson } \\
\text { diversity index } \\
(1-D)\end{array}$ \\
\hline 33 & 0.77 & 0.70 & 0.50 & 0.50 \\
\hline 34 & 0.75 & 0.68 & 0.52 & 0.48 \\
\hline 35 & 0.43 & 0.62 & 0.70 & 0.30 \\
\hline 36 & 0.76 & 0.69 & 0.52 & 0.48 \\
\hline 37 & 0.50 & 0.72 & 0.63 & 0.37 \\
\hline 38 & 0.62 & 0.89 & 0.49 & 0.51 \\
\hline 39 & - & - & - & - \\
\hline 40 & 0.66 & 0.60 & 0.61 & 0.39 \\
\hline 41 & 0.57 & 0.82 & 0.50 & 0.50 \\
\hline 42 & 0.41 & 0.59 & 0.65 & 0.35 \\
\hline 43 & 0.91 & 0.83 & 0.39 & 0.61 \\
\hline 44 & 0.46 & 0.66 & 0.66 & 0.34 \\
\hline 45 & 0.41 & 0.59 & 0.71 & 0.29 \\
\hline 46 & 0.41 & 0.59 & 0.72 & 0.28 \\
\hline 47 & 0.50 & 0.72 & 0.60 & 0.40 \\
\hline 48 & 0.64 & 0.92 & 0.46 & 0.54 \\
\hline 49 & 0.41 & 0.59 & 0.72 & 0.28 \\
\hline 50 & - & - & - & - \\
\hline 51 & - & - & - & - \\
\hline 52 & - & - & - & - \\
\hline 1 & 0.00 & 0.00 & 0.00 & 0.00 \\
\hline 2 & 0.00 & 0.00 & 0.00 & 0.00 \\
\hline 3 & 0.00 & 0.00 & 0.00 & 0.00 \\
\hline 4 & 0.00 & 0.00 & 0.00 & 0.00 \\
\hline 5 & 0.00 & 0.00 & 0.00 & 0.00 \\
\hline 6 & 0.00 & 0.00 & 0.00 & 0.00 \\
\hline 7 & 0.00 & 0.00 & 0.00 & 0.00 \\
\hline 8 & 0.00 & 0.00 & 0.00 & 0.00 \\
\hline
\end{tabular}




\begin{tabular}{|c|c|c|c|c|}
\hline SMW & $\begin{array}{l}\text { Shannon's } \\
\text { index (H') }\end{array}$ & $\begin{array}{c}\text { Pielou's } \\
\text { evenness }\left(J^{\prime}\right)\end{array}$ & $\begin{array}{l}\text { Simpson index } \\
\text { (D) }\end{array}$ & $\begin{array}{c}\text { Simpson } \\
\text { diversity index } \\
\text { (1-D) }\end{array}$ \\
\hline 9 & 0.00 & 0.00 & 0.00 & 0.00 \\
\hline 10 & 0.00 & 0.00 & 0.00 & 0.00 \\
\hline 11 & 0.00 & 0.00 & 0.00 & 0.00 \\
\hline 12 & 0.00 & 0.00 & 0.00 & 0.00 \\
\hline 13 & 0.00 & 0.00 & 0.00 & 0.00 \\
\hline 14 & 0.00 & 0.00 & 0.00 & 0.00 \\
\hline 15 & 0.00 & 0.00 & 0.00 & 0.00 \\
\hline 16 & 0.00 & 0.00 & 0.00 & 0.00 \\
\hline 17 & 0.00 & 0.00 & 0.00 & 0.00 \\
\hline 18 & 0.00 & 0.00 & 0.00 & 0.00 \\
\hline 19 & - & - & - & - \\
\hline 20 & - & - & - & - \\
\hline 21 & 0.57 & 0.82 & 0.25 & 0.75 \\
\hline 22 & - & - & - & - \\
\hline 23 & 1.04 & 0.95 & 0.16 & 0.84 \\
\hline 24 & 0.85 & 0.77 & 0.31 & 0.69 \\
\hline 25 & 1.08 & 0.98 & 0.27 & 0.73 \\
\hline 26 & 0.38 & 0.35 & 0.80 & 0.20 \\
\hline 27 & 0.90 & 0.82 & 0.45 & 0.55 \\
\hline 28 & 0.61 & 0.56 & 0.66 & 0.34 \\
\hline 29 & 0.51 & 0.46 & 0.72 & 0.28 \\
\hline 30 & - & - & - & - \\
\hline 31 & - & - & - & - \\
\hline
\end{tabular}

SMW- Standard Meteorological Weeks

(*There was no incidence of fruit flies in guava from $32^{\text {nd }}$ SMW 2017 onwards) (- Species diversity was not noticed) 
Table.3 Population dynamics of fruit flies in guava ecosystem during 2015-16

\begin{tabular}{|c|c|c|c|c|}
\hline \multirow{2}{*}{ SMW } & \multicolumn{3}{|c|}{ No./trap/week* } & \multirow{2}{*}{ Total } \\
\hline & B. dorsalis & B. correcta & B. zonata & \\
\hline 27 & 15.00 & 55.75 & 9.50 & 80.25 \\
\hline 28 & 2.50 & 25.50 & 2.50 & 30.50 \\
\hline 29 & 3.75 & 21.88 & 3.25 & 28.88 \\
\hline 30 & 2.00 & 35.50 & 2.50 & 40.00 \\
\hline 31 & 3.00 & 20.00 & 3.75 & 26.75 \\
\hline 32 & 5.00 & 25.50 & 4.50 & 35.00 \\
\hline 33 & 0.00 & 8.25 & 0.00 & 8.25 \\
\hline 34 & 6.25 & 10.25 & 0.00 & 16.50 \\
\hline 35 & 3.00 & 15.50 & 0.00 & 18.50 \\
\hline 36 & 4.00 & 20.20 & 0.00 & 24.20 \\
\hline 37 & 2.75 & 15.00 & 0.00 & 17.75 \\
\hline 38 & 3.00 & 10.50 & 0.00 & 13.50 \\
\hline 39 & 0.00 & 3.00 & 0.00 & 3.00 \\
\hline 40 & 3.00 & 3.00 & 0.00 & 6.00 \\
\hline 41 & 2.00 & 9.50 & 2.00 & 13.50 \\
\hline 42 & 5.00 & 28.75 & 2.00 & 35.75 \\
\hline 43 & 0.00 & 15.50 & 0.00 & 15.50 \\
\hline 44 & 3.50 & 11.00 & 0.00 & 14.50 \\
\hline 45 & 0.00 & 3.00 & 0.00 & 3.00 \\
\hline 46 & 0.00 & 0.00 & 0.00 & 0.00 \\
\hline 47 & 0.00 & 1.00 & 0.00 & 1.00 \\
\hline 48 & 2.00 & 2.00 & 1.00 & 5.00 \\
\hline 49 & 0.00 & 2.50 & 0.00 & 2.50 \\
\hline 50 & 0.00 & 5.00 & 0.00 & 5.00 \\
\hline 51 & 2.00 & 1.50 & 0.00 & 3.50 \\
\hline 52 & 0.00 & 1.00 & 0.00 & 1.00 \\
\hline 1 & 1.25 & 1.25 & 0.00 & 2.50 \\
\hline 2 & 0.00 & 0.00 & 0.00 & 0.00 \\
\hline 3 & 1.00 & 1.50 & 0.00 & 2.50 \\
\hline Total & 70.00 & 353.33 & 31.00 & 454.33 \\
\hline
\end{tabular}

\footnotetext{
*Average of 4 fruit fly traps

SMW- Standard Meteorological Weeks
} 
Table.4 Population dynamics of fruit flies in guava ecosystem during 2016-17

\begin{tabular}{|c|c|c|c|c|}
\hline \multirow{2}{*}{ SMW } & \multicolumn{3}{|c|}{ No./trap/week* } & \multirow{2}{*}{ Total } \\
\hline & B. dorsalis & B. correcta & B. zonata & \\
\hline 33 & 1.00 & 5.50 & 1.00 & 7.50 \\
\hline 34 & 1.00 & 7.00 & 1.50 & 9.50 \\
\hline 35 & 0.00 & 8.00 & 1.50 & 1.50 \\
\hline 36 & 2.00 & 8.00 & 1.00 & 11.00 \\
\hline 37 & 0.00 & 6.00 & 1.50 & 7.50 \\
\hline 38 & 2.00 & 4.50 & 0.00 & 6.50 \\
\hline 39 & 0.00 & 7.50 & 0.00 & 7.50 \\
\hline 40 & 1.00 & 8.50 & 1.25 & 10.75 \\
\hline 41 & 0.00 & 3.00 & 1.00 & 4.00 \\
\hline 42 & 0.00 & 3.00 & 0.50 & 3.50 \\
\hline 43 & 2.00 & 5.00 & 1.00 & 8.00 \\
\hline 44 & 0.00 & 5.00 & 1.00 & 6.00 \\
\hline 45 & 1.00 & 6.00 & 0.00 & 7.00 \\
\hline 46 & 0.00 & 6.25 & 1.00 & 7.25 \\
\hline 47 & 1.00 & 4.00 & 0.00 & 5.00 \\
\hline 48 & 2.00 & 4.00 & 0.00 & 6.00 \\
\hline 49 & 0.00 & 4.75 & 0.75 & 5.50 \\
\hline 50 & 0.00 & 1.50 & 0.00 & 1.50 \\
\hline 51 & 0.00 & 1.75 & 0.00 & 1.75 \\
\hline 52 & 0.00 & 0.25 & 0.00 & 0.25 \\
\hline 1 & 0.00 & 0.00 & 0.00 & 0.00 \\
\hline 2 & 0.00 & 0.00 & 0.00 & 0.00 \\
\hline 3 & 0.00 & 0.00 & 0.00 & 0.00 \\
\hline 4 & 0.00 & 0.00 & 0.00 & 0.00 \\
\hline 5 & 0.00 & 0.00 & 0.00 & 0.00 \\
\hline 6 & 0.00 & 0.00 & 0.00 & 0.00 \\
\hline 7 & 0.00 & 0.00 & 0.00 & 0.00 \\
\hline 8 & 0.00 & 0.00 & 0.00 & 0.00 \\
\hline
\end{tabular}




\begin{tabular}{|c|c|c|c|c|}
\hline \multirow{2}{*}{ SMW } & \multicolumn{3}{|c|}{ No./trap/week* } & \multirow{2}{*}{ Total } \\
\hline & B. dorsalis & B. correcta & B. zonata & \\
\hline 9 & 0.00 & 0.00 & 0.00 & 0.00 \\
\hline 10 & 0.00 & 0.00 & 0.00 & 0.00 \\
\hline 11 & 0.00 & 0.00 & 0.00 & 0.00 \\
\hline 12 & 0.00 & 0.00 & 0.00 & 0.00 \\
\hline 13 & 0.00 & 0.00 & 0.00 & 0.00 \\
\hline 14 & 0.00 & 0.00 & 0.00 & 0.00 \\
\hline 15 & 0.00 & 0.00 & 0.00 & 0.00 \\
\hline 16 & 0.00 & 0.00 & 0.00 & 0.00 \\
\hline 17 & 0.00 & 0.00 & 0.00 & 0.00 \\
\hline 18 & 0.00 & 0.00 & 0.00 & 0.00 \\
\hline 19 & 0.00 & 0.50 & 0.00 & 0.50 \\
\hline 20 & 0.00 & 1.00 & 0.00 & 1.00 \\
\hline 21 & 0.50 & 1.50 & 0.00 & 2.00 \\
\hline 22 & 0.00 & 1.00 & 0.00 & 1.00 \\
\hline 23 & 1.00 & 2.00 & 1.00 & 4.00 \\
\hline 24 & 1.50 & 2.50 & 0.25 & 4.25 \\
\hline 25 & 2.25 & 3.50 & 3.75 & 9.50 \\
\hline 26 & 1.75 & 19.75 & 0.50 & 22.00 \\
\hline 27 & 6.50 & 18.50 & 4.00 & 29.00 \\
\hline 28 & 9.50 & 45.50 & 2.00 & 57.00 \\
\hline 29 & 8.00 & 60.50 & 3.00 & 71.50 \\
\hline 30 & 0.00 & 2.00 & 0.00 & 2.00 \\
\hline 31 & 0.00 & 3.00 & 0.00 & 3.00 \\
\hline Total & 44.00 & 260.75 & 27.50 & 324.25 \\
\hline
\end{tabular}


Table.5 Correlation coefficients of trap catches of fruit flies with weather parameters in guava during 2015-16

\begin{tabular}{|l|c|c|c|c|c|}
\hline \multirow{2}{*}{$\begin{array}{c}\text { Fruit fly } \\
\text { species }\end{array}$} & \multicolumn{2}{|c|}{ Temperature $\left({ }^{\circ} \mathbf{C}\right)$} & \multicolumn{2}{c|}{ Relative humidity (\%) } & \multirow{2}{*}{$\begin{array}{c}\text { Rainfall } \\
\text { (mm) }\end{array}$} \\
\cline { 2 - 5 } & Maximum & Minimum & Morning & Evening & \\
\hline B. dorsalis & 0.017 & 0.326 & -0.276 & -0.073 & 0.182 \\
\hline B. correcta & 0.084 & $0.507^{*}$ & -0.271 & -0.111 & 0.501 \\
\hline B. zonata & 0.194 & $0.444^{*}$ & -0.259 & -0.126 & -0.082 \\
\hline
\end{tabular}

* Significant at $5 \%$

Table.6 Correlation coefficients of trap catches of fruit flies with weather parameters in guava during 2016-17

\begin{tabular}{|l|c|c|c|c|c|}
\hline \multirow{2}{*}{$\begin{array}{c}\text { Fruit fly } \\
\text { species }\end{array}$} & \multicolumn{2}{|c|}{ Temperature $\left({ }^{\circ} \mathbf{C}\right)$} & \multicolumn{2}{c|}{ Relative humidity (\%) } & \multirow{2}{*}{$\begin{array}{c}\text { Rainfall } \\
\text { (mm) }\end{array}$} \\
\cline { 2 - 5 } & Maximum & Minimum & Morning & Evening & \\
\hline B. dorsalis & -0.071 & -0.013 & $0.363^{*}$ & 0.206 & 0.110 \\
\hline B. correcta & -0.141 & -0.031 & $0.385^{*}$ & 0.243 & 0.099 \\
\hline B. zonata & -0.172 & -0.019 & $0.462^{*}$ & 0.206 & $0.379 *$ \\
\hline
\end{tabular}

* Significant at $5 \%$ 
Table.7 Multiple linear regression of trap catches of fruit flies with weather parameters in guava during 2015-16

\begin{tabular}{|l|l|c|}
\hline \multicolumn{1}{|c|}{ Fruit fly species } & \multicolumn{1}{|c|}{ Regression model } & $\begin{array}{c}\text { Regression coefficient } \\
\left(\mathbf{R}^{2}\right)\end{array}$ \\
\hline B. dorsalis & $\mathrm{Y}=-2.21+0.17 \mathrm{x}_{1}+0.46$ & 0.26 \\
\hline B. correcta & $\mathrm{x}_{2}-0.15 \mathrm{x}_{3}+0.03 \mathrm{x}_{4}+0.20 \mathrm{x}_{5}+2.86$ & 0.47 \\
\hline B. zonata & $\mathrm{Y}=-40.54+0.92 \mathrm{x}_{1}+3.07$ & $-1.08 \mathrm{x}_{3}+0.74 \mathrm{x}_{4}+0.97 \mathrm{x}_{5}+10.37$ \\
\hline
\end{tabular}

$\mathrm{x}_{1}=$ maximum temperature; $\mathrm{x}_{2}=$ minimum temperature; $\mathrm{x}_{3}=$ relative humidity in the morning; $\mathrm{x}_{4}=$ Relative humidity in the evening; $\mathrm{x}_{5}=$ rain fall; $\mathrm{Y}=$ number of fruit flies.

Table.8 Multiple linear regression of trap catches of fruit flies with weather parameters in guava during 2016-17

\begin{tabular}{|l|ll|c|}
\hline \multicolumn{1}{|c|}{ Fruit fly species } & \multicolumn{1}{|c|}{ Regression model } & $\begin{array}{c}\text { Regression coefficient } \\
\left(\mathbf{R}^{\mathbf{2}}\right)\end{array}$ \\
\hline B. dorsalis & $\begin{array}{l}\mathrm{Y}=- \\
11.48 \quad+0.17 \mathrm{x}_{1}+0.04 \mathrm{x}_{2}+0.03 \mathrm{x}_{3}+0.04 \mathrm{x}_{4}+0.00 \mathrm{x}_{5}+1.84\end{array}$ & 0.19 \\
\hline B. correcta & $\mathrm{Y}=-$ & 0.19 \\
\hline B. zonata & $49.11 \quad+0.61 \mathrm{x}_{1}+0.30 \mathrm{x}_{2}+0.21 \mathrm{x}_{3}+0.21 \mathrm{x}_{4}-0.06 \mathrm{x}_{5}+10.16$ & 0.29 \\
\hline
\end{tabular}

$\mathrm{x}_{1}=$ maximum temperature; $\mathrm{x}_{2}=$ minimum temperature; $\mathrm{x}_{3}=$ relative humidity in the morning; $\mathrm{x}_{4}=$ relative humidity in the evening; $\mathrm{x}$ ${ }_{5}=$ rain fall; $\mathrm{Y}=$ number of fruit flies 
Similarly, in guava, the maximum (10.76 to $14.74 \%$ ) infestation of $B$. zonata was observed in the month of August and September in Pakistan (Khan et al., 2005). Bansode (2009) noticed the occurrence of fruit flies throughout the year and peak activity coincided with fruiting and harvesting period of guava. He also observed that, the fruit fly activity was higher during June to November. Present findings are also in agreement with the Dale and Patel (2010) who reported that highest number of fruit flies, Bactrocera spp population was observed in the month of September and lowest in the month of May in the guava orchard. The activity and dominance of the fruit fly species differed, which may be attributed to different agro climatic factors and crop phenology and corresponding to fruiting period and fruit maturity.

Influence of weather parameters on population dynamics of fruit fly species in guava during 2015-16 and 2016-17

Studies were made to find out the relationship between trap catches of different species of fruit flies and weather parameters viz., maximum and minimum temperature, morning and evening relative humidity and rainfall. Influence of weather parameters on B. dorsalis population was worked out by calculating correlation coefficient of trap catches. The correlation analysis between the weather parameters and fruit fly trap catches revealed that $B$. dorsalis had no significant relationship with any of the weather parameters. B. correcta and B. zonata had a significant positive correlation with minimum temperature $\quad(\mathrm{r}=0.507 \quad$ and 0.444 , respectively). There was no significant relationship with other weather parameters during 2015-16 (Table 5). Influence of weather parameters on fruit fly population of trap catches during 2016-17, indicated that $B$. dorsalis, B. correcta and B. zonata had a significant positive correlation with morning relative humidity $(\mathrm{r}=0.363,0.385$ and 0.462 , respectively). $B$. zonata showed a significant positive correlation with rainfall $(\mathrm{r}=0.379)$. There was no significant relationship with other weather factors viz., maximum and minimum temperature and evening relative humidity (Table 6).

Multiple regression analysis on the effect of different weather parameters together on the fruit fly trap catches showed that predictability of the equation ranged from 26.7 to 47.1 per cent on fruit fly species during 2015-16. The regression model showed the highest predictability of 47.1 per cent in B. correcta while, B. zonata and $B$. dorsalis recorded 32 and 26 per cent accuracy respectively (Table 7). During 2016-17 weather factors collectively influenced trap catches of $B$. zonata to an extent of 29 per cent. The other two species, $B$. correcta and $B$. dorsalis recorded trap catches to the tune of 19 per cent (Table 8).

According to findings of Jalaluddin et al., (2001), abiotic factors played an important role in regulating $B$. correcta population. Weather parameters showed significant positive correlation with mean maximum temperature, minimum temperature, daydegrees (thermal units), morning relative humidity and rainfall. Agarwal and Deepa (2013) reported three species viz., B. dorsalis, $B$. zonata and $B$. correcta, of which $B$. correcta was predominant followed by $B$. zonata and $B$. dorsalis in horticulture ecosystems. Population of $B$. correcta was influenced by temperature, which had a positive correlation at three places, negative correlation two other places $(r=-0.034$ and 0.2811). Relative humidity negatively correlated at four locations while it showed positive correlation at Indian Institute of Pulses Research (IIPR) $(r=0.273)$. Rainfall showed a positive correlation with catches of 
B. correcta at three locations while it showed positive correlation at two places. B. zonata and $B$. dorsalis had positive correlation with temperature. Present finding are more or less similar to the earlier results. Fruit fly showed differential responses to all weather parameters due to topography and agro climatic regions. Sarada et al., (2001) found significant positive correlation of fruit fly with maximum temperature and nonsignificant positive correlation with minimum temperature. According to Rajitha and Viraktamath (2006), B. dorsalis in guava had significant positive correlation with minimum temperature and morning and afternoon relative humidity, but had significant negative correlation with maximum temperature. Abiotic factors played an important role in the regulation of $B$. correcta population; however, in the current findings it differed which might be due to the availability of the host and variation in the weather factors. However, Singh and Mann (2003) reported positive correlation between population build up and rainfall. Variation might be due to the difference in host food availability and stage of fruits.

In conclusion, the present findings indicted that diversity of fruit flies, B. duplicata in guava ecosystem is very low. The dominant species found in guava ecosystem was $B$. correcta, B. dorsalis and B. zonata. When the total fruit flies were considered irrespective of the species, the first major peak population (80.25 flies per trap/week) was observed during $27^{\text {th }}$ SMW of 2015. Considering the total number of fruit flies irrespective of the species, the first major peak (71.50 fruit flies/trap/week) was observed during $29^{\text {th }}$ SMW of (July) 2017.

\section{Acknowledgement}

The authors are grateful to Dr. K.J. David, Scientist (Agril. Entomology), Division of
Insect Systematics, ICAR-National Bureau of Agricultural Insect Resources, Bengaluru for his help in identifying fruit fly specimens.

\section{References}

Agrawal, N. and Deepa, M., 2013. Population dynamics of fruit fly species caught through methyl eugenol traps at different locations of Kanpur, Central U. P. Journal of Entomological Research. 37 (1): 87-90.

Anonymous, 2017. Indian Horticulture Database 2017, Ministry of Agriculture, Govt. of India, p. 296 http: //nhb.gov. in/area-pro/database-2014.pdf.

Accessed 28 March 2014.

Bansode, G. M., 2009. Studies on comparative biology, population dynamics and management of orchard fly (Bactrocera spp.) Ph. D. Thesis (Unpublished) submitted to Navasari Agricultural University, Navasari, Gujarat, pp -177.

Butani, D. K., 1979. Insects and fruits. Periodical Expert Book Agency, New Delhi. pp. 55.

Chaudhary, M.M.K. and Jamal, A.Q., 2002. Effect of abiotic factors on population fluctuation of Oriental and peach fruit flies at Rawalpindi, Pakistan. Pakistan Journal of Zoology. 32, 182-185.

Dale, N. S. and Patel, R. K., 2010. Population dynamics of fruit flies (Bactrocera $\mathrm{spp}$ ) on guava and its correlation with weather parameters, Current Biotica. 4 (2): 245-248.

David, K. J. and Ramani, S., 2011. An illustrated key to fruit flies (Diptera: Tephritidae) from Peninsular India and the Andaman and Nicobar Islands. Zootaxa. 3021: 1-31.

Drew, R. A. I. and S. Raghu., 2002. The fruit fly fauna (Diptera: Tephritidae: Dacinae) of the rainforest habitat of the Western Chats, India. Raffles Bulletin of 
Zoology. 20: 327-352.

Jalaluddin, S. M., Natarajan, K. and Sadakathulla, S., 2001. Population fluctuation of the guava fruit fly, Bactrocera correcta (Bezzi) in relation to hosts and abiotic factors. Journal of Experimental Zoology. 4: 323-327.

Kadam, U. K., 2012. Studies on species diversity, population dynamics and management of fruit flies in guava (Psidium guajava L.). Ph. D thesis, Mahatma Phule Krishi Vidyapeeth, Rahuri-413 722, dist. Ahmednagar, Maharashtra, India 1-160 pp.

Khan, M. A., Muhammad, A., Waessem, A. and Lee, L. L., 2005. Management of fruit flies of the most perishable fruit. Entomological Research. 35 (2): 79-84.

Nagaraj, K. S., Jaganath, S., Raveendra, Y. C. and Srikanth, L., 2014. Species complex of fruit flies and their relative abundance in methyl eugenol traps in mango orchard. Trends in Biosciences. 7 (12): 1234-1245.

Pielous, E. C., 1969. An Introduction to Mathematical Ecology. Wiley, New York, NY, 286 pp.

Rajitha, A. R. and Viraktamath, S., 2005. Efficiency of different types of traps in attracting fruit flies in guava orchard at Dharwad, Karnataka. Pest Management in Ecological Zoology. 13: 111-120.

Rajitha, A. R. and Viraktamath, S. 2006. Monitoring of fruit flies (Diptera:
Tephritidae) in guava orchard at Dharwad, Karnataka. Karnataka Journal of Agricultural Sciences. 19: 45-49.

Ravikumar, P. 2006. Studies on fruit fly trapping systems using methyl eugenol and protein food baits in guava and mango orchards. M. Sc. Thesis, Uni. Agric. Sci., Dharwad (India). p 81.

Sarada, G., Maheswari, T. U. And Purushotham, K. 2001. Seasonal incidence and population fluctuation of fruit flies in mango and guava. Indian Journal of Entomology. 63 (3): 272276.

Shannon, L. E. and Wiener, W. 1949. The mathematical theory of communication. University of Illinois Press, Urban, $\mathrm{p}$ 11.

Simpson, E. J. 1949. Measurement of diversity. Nature, 163, 688.

Singh, P. and Mann, G. S. 2003. Population studies of fruit fly, Bactrocera dorsalis (Hendel) on peach. Journal of Insect Science. 16: 24-28.

Verghese, A. and Sudhadevi, K. 1998. Relation between trap catch of Bactrocera dorsalis Hendel and abiotic factors. In: Reddy, P. P., Kumar, N. K. K., Verghese, A. (Eds.), Advances in IPM for Horticultural Crops. Proceedings of I National Symposium on Pest Management In Horticulture Crops. Bangalore, India, pp. 15-18.

\section{How to cite this article:}

Mahesh Math, Y.K. Kotikal and Ganiger, V.M. 2018. Species Diversity and Population Dynamics of Fruit Flies in Guava Ecosystem. Int.J.Curr.Microbiol.App.Sci. 7(12): 2269-2283. doi: https://doi.org/10.20546/ijcmas.2018.712.258 